\title{
Surgical Strategies for the Removal of Sphenoorbital Meningiomas
}

\section{Sfenoorbital Menenjiyomlarm Çıkarulmasında Cerrahi Stratejiler}

\author{
Ilker SOLMAZ, Ozkan TEHLI, Caglar TEMIZ, Cahit KURAL, Irgen HODAJ, Murat KUTLAY, \\ Engin GONUL, Mehmet K. DANEYEMEZ
}

Gulbane Military Medical Academy, Department of Neurosurgery, Ankara, Turkey

Corresponding Author: Ilker SOLMAZ / E-mail: solmazilker@hotmail.com

\begin{abstract}
AIM: Surgical removal of sphenoorbital meningiomas is challenging for neurosurgeons. The aim of study is to share our experience on sphenoorbital meningiomas and to provide a picture of the current state of the art in surgical treatment of these tumors.

MATERIAL and METHODS: The data of 13 cases of sphenoorbital meningioma who were operated between 2006 and 2013 was reviewed retrospectively. Intraorbital extension was present in 10 cases while sphenoid bone invasion was detected in 9 cases. All patients underwent surgical treatment after the radiological evaluation with magnetic resonance imaging and computed tomography. The degree of resection and the clinical outcome of all patients were analyzed.

RESULTS: Extended pterional approach with a large frontotemporal craniotomy was performed in all cases. Simpson's grade I and II excision was achieved in 4 (31\%) cases while subtotal excision (Simpson's grade III or higher) was performed in 9 cases. The main reason for subtotal excision was the cavernous sinus invasion. Optic canal decompression was performed in patients with intraorbital invasion.

CONCLUSION: Although total removal is the main objective of surgery, the sphenoorbital meningiomas are difficult to resect especially with cavernous sinus invasion. But in the meantime, it is not recommended to take any excessive risks to achieve a greater degree of resection for a benign tumor. Endoscopic approach is an option for inferomedial orbital parts of these tumors.
\end{abstract}

KEYWORDS: Sphenoorbital meningioma, Surgery, Strategy

öz

AMAÇ: Sfenoorbital menenjiyomların cerrahi yolla çıkartılması nöroşirürjiyenler için oldukça zorlu bir süreçtir. Çalışmanın amacı, sfenoorbital menenjiyomlar konusunda tecrübelerimizi paylaşmak ve bu tümörlerin cerrahi tedavisi konusunda güncel yaklaşımları ortaya koymaktır.

YÖNTEM ve GEREÇLER: 2006-2013 yılları arasında opere edilen 13 adet sfenoorbital menenjiyom olgusunun verileri geriye dönük olarak incelendi. On olguda intraorbital yayılım ve 9 olguda sfenoid kemik invazyonu saptandı. Tüm hastalara bilgisayarlı tomografi ve manyetik rezonans görüntülemenin ardından cerrahi tedavi uygulandı. Hastalarda tümör rezeksiyon derecesi ve klinik sonuçlar analiz edildi.

BULGULAR: Tüm olgulara geniş bir frontotemporal kraniyotomi ile genişletilmiş pterional yaklaşım uygulandı. Simpson derece I ve II eksizyon 4 (\%31) olguda sağlanırken, subtotal eksizyon (Simpson derece III veya daha yüksek) 9 olguda sağlandı. Subtotal eksizyonun en önemli sebebi kavernöz sinüs invazyonu idi. Optik kanal dekompresyonu intraorbital invazyon olan olgularda uygulandı.

SONUÇ: Sfenoorbital menenjiyomların cerrahi tedavisinde ana hedef her ne kadar total eksizyon olsa da özellikle kavernöz sinüs invazyonu olan olgularda bu hedefe ulaşmak zordur. Aynı zamanda iyi huylu bir tümör için daha fazla rezeksiyon amacıyla yüksek risk alınmasına gerek yoktur. Bu tümörlerin inferomedial orbital kısımlarının çıkartılmasında endoskopik yaklaşım da bir seçenektir.

ANAHTAR SÖZCÜKLER: Sfenoorbital menenjiyom, Cerrahi, Strateji

\section{INTRODUCTION}

Meningiomas are the second most common primary tumors of the central nervous system. They are usually slow growing and present as a solitary tumor or may be associated with other types of tumor $(15,25)$. Sphenoorbital meningiomas (SOM) arise from the greater sphenoid wing and show extension to the orbit, anterior and middle fossa and zygomatic fossa (5). These tumors are rare and slow-growing lesions but may cause hyperostosis and intraosseous tumors or both. SOM may disseminate intradurally or extradurally. Intradural extension may be in various forms from a thin lesion to the large en-plaque meningiomas. Hyperostosis is commonly seen in whole skull base but especially involve the walls of superior orbital fissure (SOF) and optic canal (OC) $(1,13,19)$. The differential diagnosis includes osteoma, fibrous dysplasia and osteoblastic metastasis of the skull (20). Large cranial or orbitocranial osteomas may mimic SOM and cause proptosis $(14,23)$. But dural invasion is not seen in patients with these lesions. SOM may also invade the cavernous sinus and affect the neural and vascular structures within this sinus.

Exophthalmos is the characteristic sign of the SOM. Disturbance in eye movements, decreased visual acuity and 
ocular pain are the other prominent findings. Compression of the cranial nerves in the SOF, OC and cavernous sinus is the cause of these symptoms $(10,27)$.

Intradural and extradural approach with large frontotempotal craniotomy is the main technique for surgical removal of SOM $(1,4)$. But frontotemporal craniotomy is usually difficult in these patients because of hypertrophic sphenoid wing and temporal bone. SOF and cavernous sinus invasions may hamper radical resection of the tumor and constitute greater risks for cranial nerve palsies related to surgery $(19,20)$. Mortality is not a significant risk of surgery, but several morbidities may present due to location and invasion of the tumor.

These tumors have long been known to induce changes in adjacent bone, including hyperostosis and direct invasion (6). SOM cause hyperostosis in sphenoid wing and this is usually observed in the $1 / 3$ outer part of the sphenoid wing and temporal bone (20). Although many surgical approaches exist for SOM, the selection of best surgical approach is mainly dependent to the location and extension of the tumor in association with the symptoms of the patients.

In this paper, we tried to determine the surgical strategy for the removal of SOM, to share our experience with these infiltrative tumors and to provide a picture of the current state of the art in surgical treatment of these tumors.

\section{PATIENTS and METHODS}

Thirteen patients underwent surgery for SOM between 2006 and 2013 in our department. Ten patients (77\%) were male and 3 patients were female with a mean age of 34 years (ranged between 26 and 58 years). All patients underwent detailed neurological, ophthalmological and radiological examinations. Ophthalmological findings (changes in visual acuity or alterations in visual fields), neurological signs, the duration of these findings, as well as exophthalmos in radiological studies were recorded. Preoperative radiological studies (magnetic resonance imaging (MRI) and computed tomography $(\mathrm{CT})$ ) were performed in all patients and the images were analyzed to determine the degree of invasion of surrounding anatomical structures. Periorbital invasion, infiltration of the dura mater, and the cavernous sinus invasion by tumor were evaluated using MRI images (Figure 1A-F). The osseous extension of the tumor was evaluated by $\mathrm{CT}$ scans (Figure 2A-D).

All patients underwent surgical treatment. The patient's head is fixed in a 3-pins head holder and rotated $45^{\circ}$ to the contralateral side. Intraoperative navigation system was

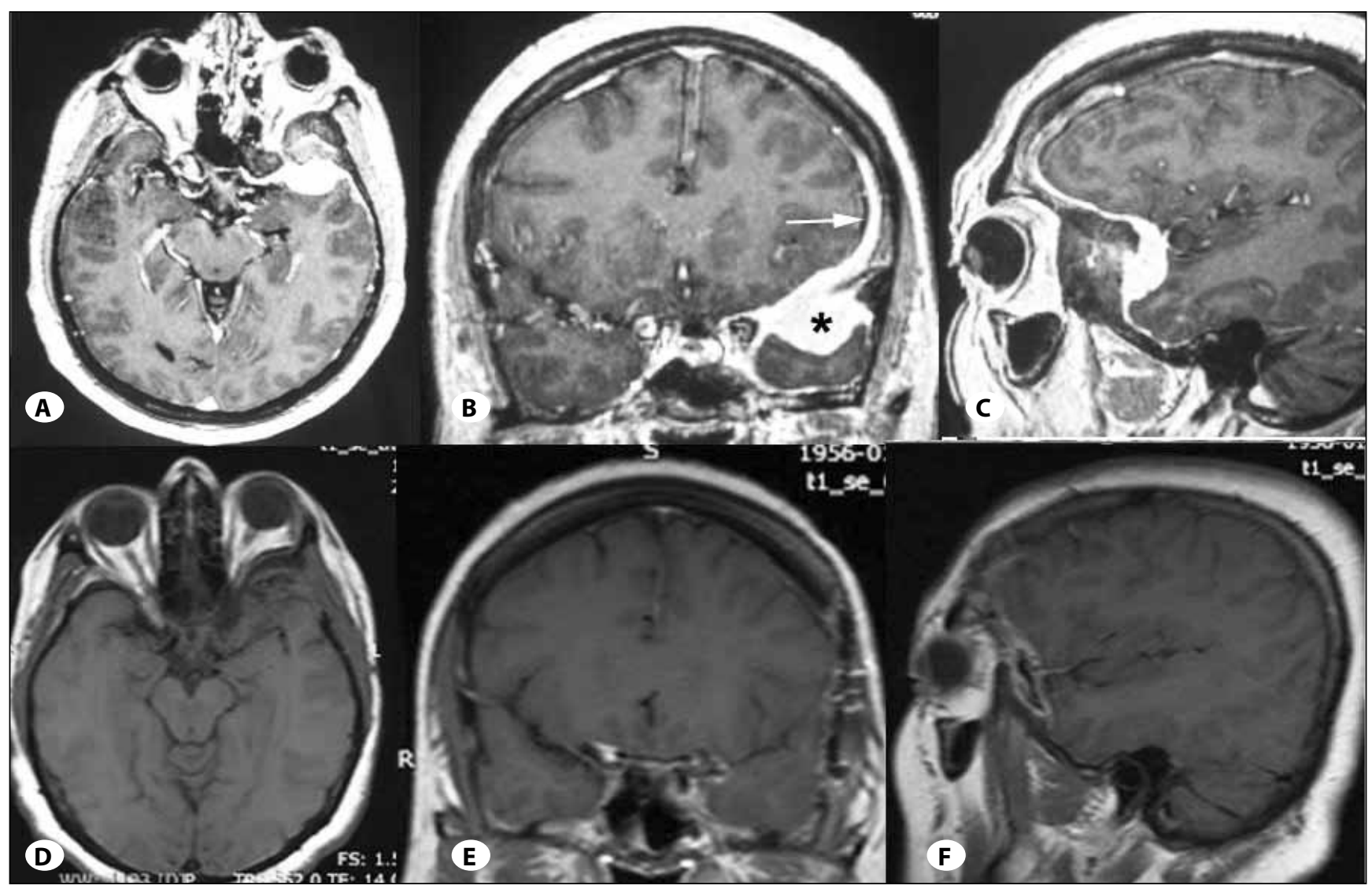

Figure 1: The A) axial, B) coronal and C) sagittal MRI scans of a female patient show left sphenoorbital contrast enhancing meningioma. The dural invasion was shown with the white arrow. Asterisk shows the tumor (B). The postoperative D) axial, E) coronal and F) sagittal MRI scans show the resection of the tumor. 


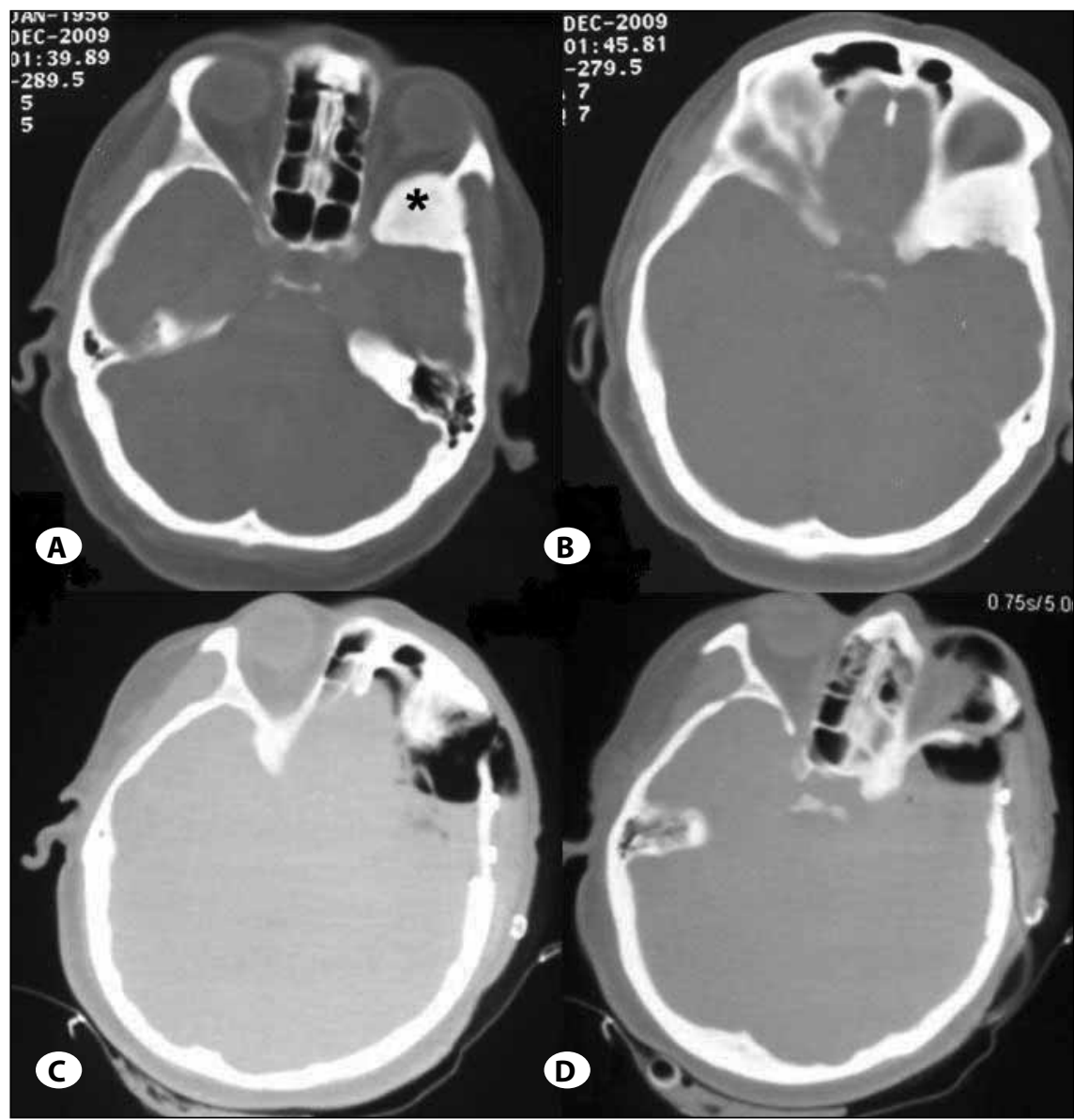

Figure 2: The preoperative CT scans $(\mathbf{A}, \mathbf{B})$ of a patient with bony invasion. Black asterisk show the hypertrophic sphenoid bone. The postoperative CT scans (C,D) after the drilling the sphenoid bone revealed the resection of the bony invasion. set-up and used to localize the limits of tumor. This system is especially important for the previously operated cases in order to target the tumor (Figure 3A-D). After a frontotemporal skin incision, cutaneous and subcutaneous tissues are cut in association with superficial temporalis muscle as a single layer fashion. Large frontotemporal craniotomy was performed and the dura was exposed in order to visualize the limits of tumor. Frontoorbitozygomatic craniotomy was used in case of large sphenoorbital tumors if the OC decompression was required (Figure $4 A-D$ ). The craniotomy was difficult when the sphenoid or temporal bone was hypertrophic due to tumor invasion. The type of orbital osteotomy and the size and shape of the craniotomy were determined for each patient based on the tumor location and extension. The sphenoid bone was exposed for the drilling of bony invasion in the first step of operation. When the bone invasion was observed, the tumoral mass was removed using high speed drill and the bleedings in the bone were stopped with bone wax. During the drilling, intraoperative $\mathrm{CT}\left(\mathrm{O}\right.$-arm ${ }^{\circledast}$ Surgical Imaging System, Medtronic, USA) was used to check the resection limits of the bone. Secondly, the temporopolar dura was entirely exposed and dissected until the OC, orbit and SOF. The SOF was usually compressed by the meningioma or by the hypertrophic bone. So, this fissure was decompressed during the tumor removal and drilling of the bone. Then, the $\mathrm{OC}$ was opened by high speed drill and the optic nerve was exposed. During this section, the posterior and lateral walls of the orbit were also drilled and removed. After the unroofing the orbit, periorbita and superior rectus muscle were preserved due to risk of enophthalmus after surgery. In addition, continuous irrigation was performed during the drilling of orbital walls. When there was a tumor around the optic nerve, the falciform ligament and optic sheet were opened and tumor was removed. In case of inferomedial orbital or nasal tumor extension, endoscope (Storz endoscope ${ }^{\circledR}$, Karl Storz, Germany) was used and the orbital part of the tumor was removed using transnasal endoscopic approach under the MRI-based or CT-based navigation control (Stealth Station ${ }^{\circledast}$, Medtronic, USA) (Figure $5 A-D)$. After the decompression of orbit and optic nerve, the dura was opened to check and remove the intradural part of the meningioma. During this stage, the involved part of the dura was also removed until the tumor-free parts of the dura were exposed. Duraplasty using fascia lata was performed after the removal of dural tumor. Posterior and lateral walls of the orbit were reconstructed using porous polyethylene to prevent the pulsatile exophthalmos after surgery.

All patients underwent radiological examination with $\mathrm{CT}$ and MRI scans to determine the extension of surgical resection. The mean follow-up period was 26.2 months, ranged between 9 and 56 months. The radiological and clinical data were analyzed preoperatively and compared with postoperative results. 


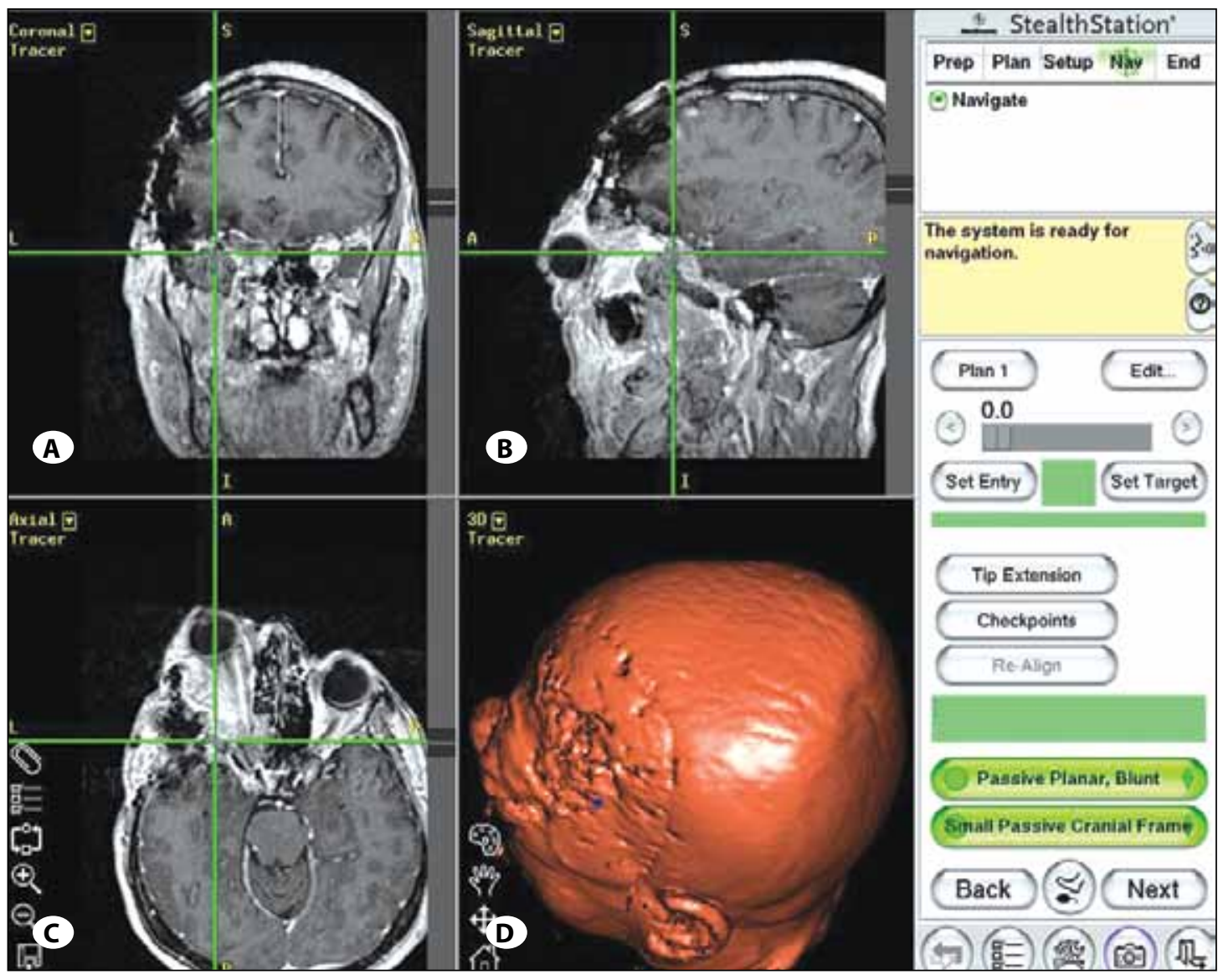

Figure 3: $\mathrm{MRI}-$ based navigation system was used in a previously operated patient in another clinic. The A) coronal, B) sagittal and

C) axial preoperative MRI slices were used for navigation.

D) The images were reconstructed and 3-D picture of the patient was obtained. The residual tumor tissue was targeted using this navigation system.

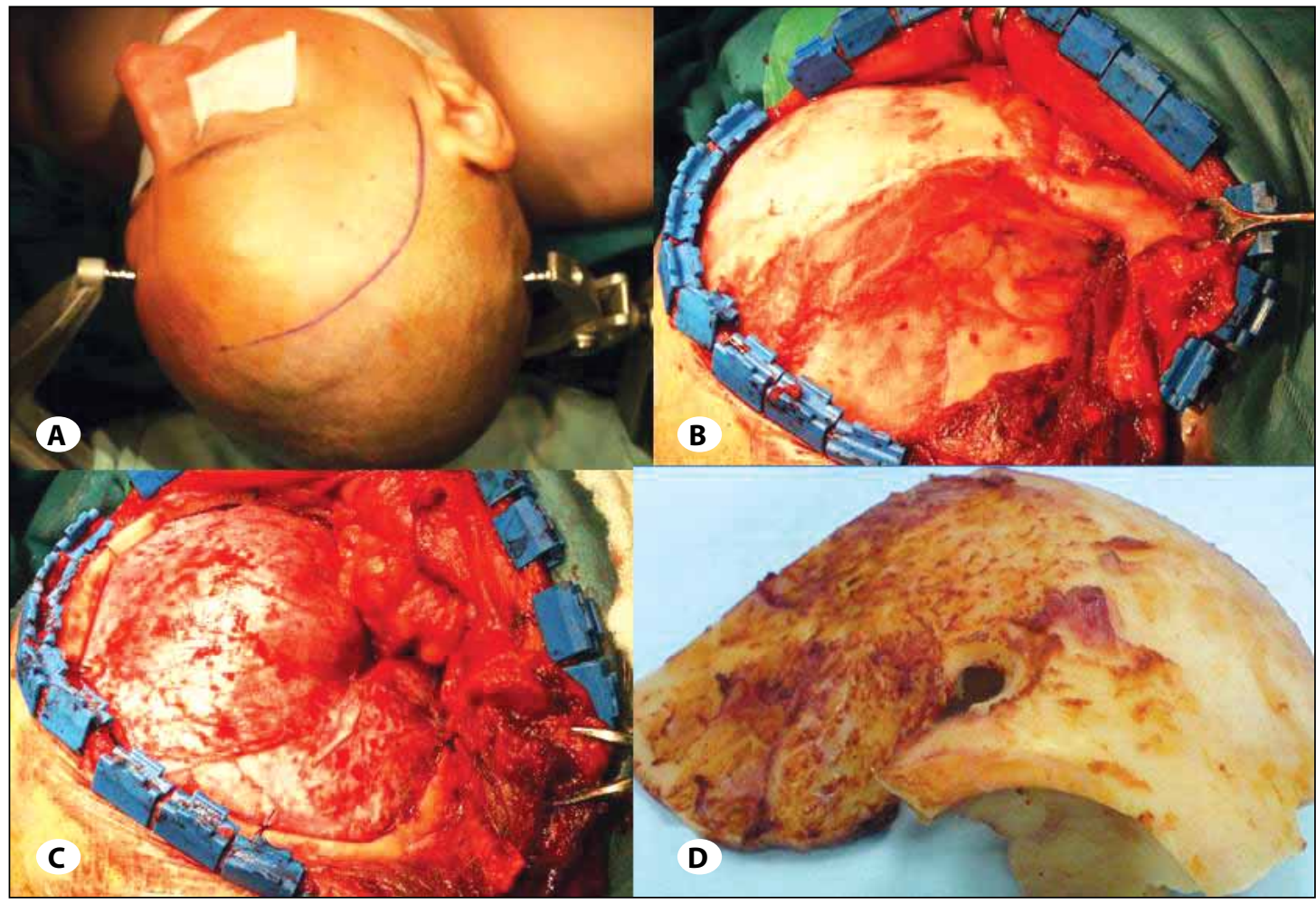

Figure 4: Frontoorbitozygomatic (FOZ) craniotomy was performed in case of SOF decompression is required during the surgery. A) Skin incision, B) exposure after the temporal muscle dissection, C) dural exposure after the FOZ craniotomy and D) the bone flap are shown in these figures. 


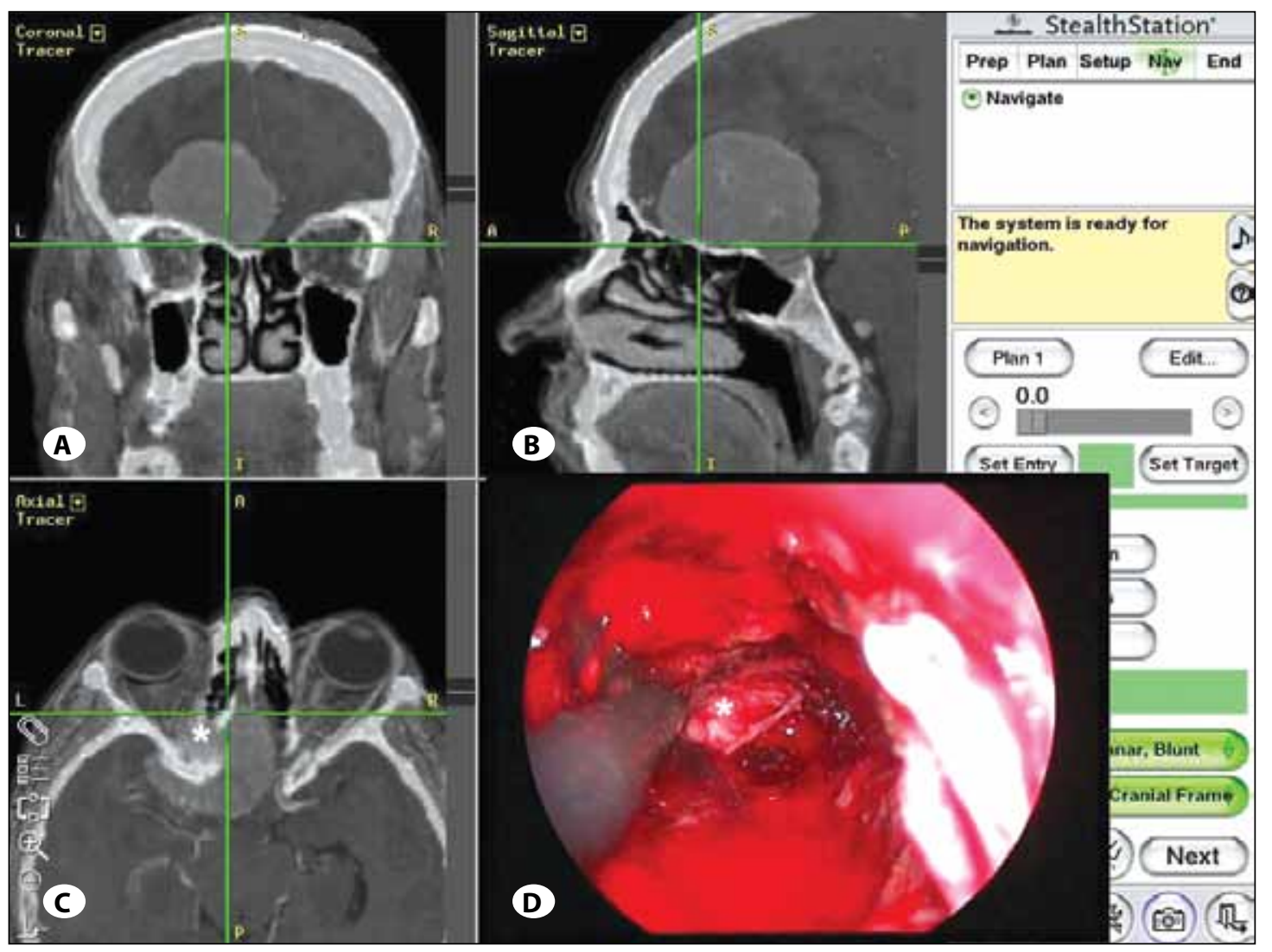

Figure 5: $A, B, C$ ) The intraoperative view of CT-based navigation system of a patient with a large sphenofrontoorbital meningioma. D) The tumor has a big frontal extension and also nasal extension. The nasal and orbital parts were removed using endoscope and navigation in the same session. Asterisk shows the tumor.

\section{RESULTS}

Exophthalmos was the most prominent symptom and observed in 10 (77\%) of 13 patients. Decreased visual acuity was present preoperatively in 8 patients (62\%), painful proptosis in 3 patients, facial pain and hypoesthesia in 2 patients, cranial nerve palsy in 2 patients and epilepsy in one patient. The median duration of preoperative symptoms was 8 months (1-36 months). None of these tumors were discovered incidentally. The mean tumor diameter was 4.2 $\mathrm{cm}$ (range 1.8-8.2 cm). The radiological examination revealed intraorbital extension in $10(77 \%)$ cases while sphenoid bone invasion was detected in 9 cases.

Total resection (Simpson's grade I and II) was obtained in $4(31 \%)$ cases. Subtotal resection (Simpson's grade III and higher) was obtained in 9 cases. The intradural portion of the tumor was removed totally in all cases. Invasion of the cavernous sinus and SOF by the tumor was the main limitation for complete resection of tumor. The mean residual tumor diameter was $1.6 \mathrm{~cm}$ (range $0.8-2.6 \mathrm{~cm}$ ) in cases with subtotal resection. All of the tumors were solid and none of them had cystic components.

The histological diagnosis of all tumors was meningioma grade I. Clinical exophthalmos was improved in $8(80 \%)$ of 10 patients, and it was unchanged in $2(20 \%)$ cases. Visual acuity was improved in 6 (75\%) of 8 patients, while no improvement was observed in 2 cases during the follow-up period. Facial and orbital pains were improved in all 5 patients. Cranial nerve palsy and epilepsy were not improved despite the removal of tumor. No recurrence was observed in the follow-up period of the patients. No re-operation or radiotherapy was performed for residual tumors in our patients after surgeries.

\section{DISCUSSION}

SOM are slow-growing lesions, and usually associated with hyperostosis involving the bone around the orbit. SOM are rare with a reported frequency of $0.2-9 \%$ of all intracranial meningiomas (22). SOM was described for the first time by Cushing and Eisenhardt $(6,7)$, and the first operative results were published by Dandy (8). Since the first description of these tumors, many papers were published in the literature $(3,4,8,12,13)$. However, the surgical results were discouraging and conservative approach was proposed because of high rates of recurrence in $\operatorname{SOM}(12,22)$.

Surgical strategy for the removal of SOM is determined by dimension and extension of the tumor in association with the degree of bony invasion and its relations to the surrounding structures. Furthermore the need for the reconstruction of orbit, dura and cranium has a great influence on the surgical technique $(5,10)$. Various surgical approaches including transzygomatic, frontoorbitozygomatic, frontotemporal, and pterional approaches, have been proposed for the removal of SOM. The aims of these approaches are the complete resection of all macroscopically visible tumors in osseous, 
intradural, and periorbital compartments (22). Many surgeons have advocated orbital reconstruction, especially when the bone removal involves 2 orbital walls (22). Chambless et al. (5) suggested porous polyethylene for the reconstruction of the orbit after resection of sphenoorbital meningioma. They pointed out that the reconstruction of the orbit with this implant shows excellent cosmetic and functional outcomes and does not cause artifacts in postoperative images. We also reconstructed the roof and lateral wall of the orbit with porous polyethylene after removal of tumor. This material is easy to handle, shape and fixate. We secured this implant to the bone with titanium screws. These implants did not effect the postoperative imaging studies in our patients.

Recently, some authors have proposed symptom-oriented surgery for the treatment of SOMs. The aim of this strategy is to decompress the optic nerve when there is decreased visual acuity, and to treat the exophthalmos $(19,22)$. Our strategy for these tumors is not only relief the symptoms but also remove the tumor as much as possible. Residual tumors may grow in a long-time period, may cause similar symptoms after many years and require re-operation with the same technique. But the presence of granulation tissues around the tumor site make difficult the second operation. Therefore, complete resection, as much as possible, is required in the first operation in order to prevent the recurrence of the tumor. In addition, navigation system may require to reach the tumor in re-operated patients.

Complete resection of all anatomical structures involved by the tumor, including the bone, periorbita, and dura is the radical surgery for $\operatorname{SOM}(21,22)$. But complete resection does not seem achievable without risk of complication because of the infiltrative nature of this disease and its tendency to spread over the dural surface (22). When all macroscopically visible tumor is removed totally and confirmed by postoperative MRI and CT images, this is considered as complete or total resection in many papers $(5,18,19,21,22)$. SOF, cavernous sinus, and extraocular muscles are the main anatomical structures limiting the radical surgical resection. Tumoral infiltration of other nearby structures including infratemporal fossa, periorbita, and sphenoid sinus may be resected without significant risk of complication $(4,21,22)$. In our series, we achieved complete resection in $31 \%$ of the patients and confirmed with MRI scans.

There are 9 large clinical series in the literature on the surgical treatment of sphenoorbital meningiomas. Two different strategies were mainly reported in these series. Some of the authors began surgery with large frontotemporal craniotomy and the others began with the drilling of hyperostosis and followed by frontotemporal craniotomy. Gaillard et al. (10) reported a series of 20 patients with sphenoorbital en-plaque meningioma in 1997 and they resected these tumors by frontotemporal craniotomy extended to the orbitozygomaticomalar bone ridge. They performed craniofacial reconstruction in the same session by different bonegrafts. They suggestediliac boneautograftforcraniofacial reconstruction because it could be modeled easily to the desired shape. They also emphasized that the reconstruction protocol should be modified as necessary according to the tumor extent and clinical considerations. Carrizo and Basso (4) reported a series of 25 cases of sphenoorbital meningioma in 1998 and they emphasized that the main obstacle of total resection is the cavernous sinus invasion and orbital apex extension of the tumor (4). They began the surgery with the drilling of hyperosteosis in the pterion and bony removal until the dura mater and periorbita were exposed. Then, they created a free basal frontotemporal flap and removed intradural part of the tumor. Finally, they reached the orbit and resected the intraorbital parts of the tumor. After the resection of intraorbital tumor, they performed periorbital reconstruction with methyl methacrylate and dural reconstruction with periosteal flap. They observed recurrence in 4 cases of their series. Shrivastava et al. (24) reported a series of 25 cases in 2005 and they performed intradural and extradural approaches to their cases. They also began the surgery with the removal of thickened hyperostosis. Then, they removed dural and intradural parts of the tumor. Lastly, they resected the intraorbital tumor. They pointed out that orbital canal should be drilled and orbital osteotomy should be performed if necessary. They reconstructed the dura with a free flap by using an acellular dermis patch. The lateral wall of the orbit was reconstructed by split cranial bone graft and orbital skeletal reconstruction was done by porous polyethylene. The convexity bone defect was closed with a titanium mesh cranioplasty. They reported transient cranial nerve palsy in a few cases but there was no mortality in this series. Sandalcioglu et al. (21) reported a series of 16 patients with sphenoorbital meningiomas and they emphasized that these tumors could be gross totally resected by combined skull base approaches with a long-term survival free of recurrence and an acceptable quality of life. They performed tumor removal and bony reconstruction in the same surgical procedure. Frontotemporal craniotomy was performed as a first stage of surgery and then they resected the bony invasion until the frontal and temporal dura. During the resection of infiltrated dura, they did not made aggressive effort to remove the tumor infiltrating cavernous sinus and deep orbital soft tissue. They performed dural reconstruction using galeal flap and orbital reconstruction using split calvarial bone flap. They performed complete tumor removal in $69 \%$ of the patients and they did not perform complete resection in other patients due to cavernous sinus and pterygopalatine fossa invasions. Ringel et al. (18) published their series of 63 patients with sphenoorbital meningiomas in 2007 and they concluded that the complete resection of these tumors is frequently impossible due to involvement of delicate structures in the orbital cone. Large frontotemporal craniotomy was preferred by the authors to resect the tumor-infitrated parts of the convexity dura. Then, the tumor-infiltrated bone was drilled and removed via extradural approach. In the last part of surgery, they removed the orbital parts of the tumor. In this paper, the authors pointed out that the surgical aim for these tumors should be the relief of leading symptoms 
rather than radical resection. Scarone et al. (22) reported their series of 30 patients with sphenoorbital meningiomas in 2009 and no mortality was reported in this series. But they also reported no Simpson grade 0 resection among the patients due to superior orbital fissure and cavernous sinus invasion. Cannon et al. (3) published the outcomes of 12 patients with sphenoorbital meningiomas in 2009 and they also pointed out the difficulty of complete resection of such tumors. According to these authors, outcomes from surgical decompression may not be better than the natural history of these tumors. They suggested that the craniotomy should expose the anterior and middle cranial fossa in addition to the lateral part of the sphenoid wing. Oya et al. (17) also reported a series of 39 patients with sphenoorbital meningioma in 2011 and they emphasized the necessity of intradural and intraorbital surgery for the removal of these tumors. Orbital reconstruction is necessary after the removal of the orbital part of the tumor. Drilling of the lateral wall of superior orbital fissure may cause transient cranial nerve palsies in these patients. Total resection is usually impossible due to cavernous sinus invasion. The largest series of sphenoorbital meningiomas was reported in 2011 by Saeed et al. (19) and they emphasized that the aim of surgery should not be total resection of tumor but improve the visual acuity and proptosis of the patients. There was no mortality in this series but recurrence rate was $17 \%$ among them. Cranial nerve palsies ( 3,4 and 5 cranial nerve) were the main complication of surgery in this series. Saeed et al. (20) also advocated «wait and see» policy in patients without risk factors. Follow-up examination in every 6 months was also recommended by the same authors for patients who had large SOM, tumor with a large soft tissue component at the first admission or rapidly growing SOMs (more than $1 \mathrm{~cm}^{3} /$ year) (20).

Meningiomas are solid tumors and cystic areas are relatively rare in these tumors (11). Cystic meningiomas are uncommon and the locations are mainly the cerebral convexity and sphenoid ridge (26). But the morphology of tumor does not affect the surgical strategy for SOM. In our series, all meningiomas were solid tumors and none of them had cystic nature. We easily dissected the tumors from the adjacent structures, but small parts of tumors around the cavernous sinus and SOF were left in place in 9 cases due to risk of neurological deficits.

Surgery is the main treatment method of intracranial meningiomas. Although most of these tumors can be easily resected by surgical interventions, some parts may remain in place due to difficult location and risk of mortality and morbidity. On the other hand, meningiomas may re-occur after the first surgery. In case of residual or recurrent meningioma, there are various treatment options such as radiotherapy and chemotherapy (9). Radiotherapy is the first option for the residual or recurrent cases of SOM. The cavernous sinus or SOF parts of these tumors are usually left in place due to risk of additional deficits and stereotactic radiosurgery is a good option for these residual parts. In our series, we performed
Simpson's grade III or high resection in 9 patients, but we did not perform radiotherapy for them because all of them were histologically grade I meningioma. They were followed-up by MRI scans after surgery and no regrowth was observed.

It is very important to determine the limits of bone drilling during the SOM surgery. Lack of precise landmarks on the sphenoid bone due to tumor invasion make difficult the drilling of bony invasion. In our series, we performed large frontotemporal craniotomy in order to expose the sphenoid wing, anterior and middle cranial fossa and orbital roof. Then we aimed to drill and remove the bony invasion of the tumor using high speed drill and navigation system. We checked the limit of resection by intraoperative CT scan and we stopped drilling when we reached to the normal bone structure. Following the resection of bony invasion, we resected the infiltrated dura and the dural attachments of the tumor. Once the adequate decompression of the middle fossa had been achieved, the superior orbital fissure and optic canal was decompressed using high speed drill. Microsurgical techniques were used for the prevention of delicate structures in the SOF and cavernous sinus. The orbital part of the tumor was resected by superior orbitotomy. Orbital muscles, especially rectus superior muscle are particularly important during the superior orbitotomy and resection of orbital parts of these tumors. The thickness of the superior rectus muscle may become very thin with the pressure of tumor and may be injured during the surgery (16). Particular attention was paid for the preservation of this muscle and other vascular and neural structures of the orbit. Orbital reconstruction by porous polyethylene and dural repair by periosteal flap were performed after the tumor removal. Tumors infiltrating the cavernous sinus were left in place due to risk of neurological deterioration. Our surgical technique is similar to the literature. But we used intraoperative imaging and navigation systems for the confirmation of the limits and amount of tumor resection in bony structures. In addition, we used endoscope in case of inferomedial orbital or nasal tumor extension. Endoscope was used and inferomedial orbital part of the tumor was removed using transnasal endoscopic approach under the CT-based or MRI-based navigation. Endoscope provides good exposure and removal of the inferior parts of these tumors with minimal invasive surgery. Recently, Attia et al. (2) reported 3 cases of recurrent SOM and they emphasized that the combined approach involving endonasal endoscopic and orbitozygomatic approaches, is very effective for the resection of SOMs invading the paranasal sinuses (2). By this surgical strategy, our total resection ratio was $31 \%$ and this result is similar to the relevant series. Although latest technological instruments were used for our patients, critical neurovascular structures hindered the high rate of total resection.

The only limitation of our study is the low number of patients in a limited time period (7 years). Sphenoorbital meningiomas are rare and difficult to achieve larger clinical series. So, our surgical strategy is depicted on these 13 cases. 


\section{CONCLUSION}

After the review of the all paper in the literature and based on our experience, one could be said that cavernous sinus and SOF invasion hinder the total resection of the tumor. Therefore, the surgeon should not aimed the total resection due to risk of cranial nerve palsy. Modern technological instruments should be used in order to determine the limits of resection and ensure good surgical result.

\section{REFERENCES}

1. Akdemir G, Cavus G: Spheno-orbital meningiomas. Turk Norosir Derg 21: 126-130, 2011 (in Turkish)

2. Attia M, Patel KS, Kandasamy J, Stieg PE, Spinelli HM, Riina HA, Anand VK, Schwartz TH: Combined cranionasal surgery for spheno-orbital meningiomas invading the paranasal sinuses, pterygopalatine, and infratemporal fossa. World Neurosurg 80: e367-373, 2013

3. Cannon PS, Rutherford SA, Richardson PL, King A, Leatherbarrow $B$ : The surgical management and outcomes for spheno-orbital meningiomas: A 7-year review of multidisciplinary practice. Orbit 28: 371-376, 2009

4. Carrizo A, Basso A: Current surgical treatment for sphenoorbital meningiomas. Surg Neurol 50: 574-578, 1998

5. Chambless LB, Mawn LA, Forbes JA, Thompson RC: Porous polyethylene implant reconstruction of the orbit after resection of spheno-orbital meningiomas: A novel technique. J Cranio-Maxillofac Surg 40:e28-e32, 2012

6. Cushing HW: The meningiomas (dural endotheliomas): Their source, and favoured seats of origin. Brain 5: 282-316, 1922

7. Cushing HW, Eisenhardt L: Meningiomas: Their classification, regional behaviour, life history and surgical end results. Springfield IL: Charles C Thomas, 1938

8. Dandy WE: Results following the transcranial operative attack on orbital tumors. Arch Opthal 25: 191-216, 1941

9. Engelhard HH: Current status of radiation therapy and radiosurgery in the treatment of intracranial meningiomas. Neurosurg Focus 2(4):e6, 1997

10. Gaillard S, Pellerin P, Dhellemmes P, Pertuzon B, Lejeune JP, Christtianes JL: Strategy of craniofacial reconstruction after resection of spheno-orbital "en plaque" meningiomas. Plast Reconstr Surg 100:1113-1120, 1997

11. Gocmen S, Topuz AK, Atabey C, Güven G, Demircan MN, Berber U: Cystic meningiomas: Report of three cases. Gulhane Med J 53(1): 69-73, 2011

12. Guiot $G$, Derome $P: A$ propos des méningiomes en plaque du ptérion: Le traitement chirurgical des méningiomes osseux hyperostosants. Ann Chir 20:1109-1127, 1966

13. Honig S, Trantakis C, Frerich B, Sterker I, Schober R, Meixensberger J: Spheno- orbital meningiomas: Outcome after microsurgical treatment: A clinical review of 30 cases. Neurol Res 32: 314-325, 2012
14. Izci Y: Management of the large cranial osteoma: Experience with 13 adult patients. Acta Neurochir (Wien) 147: 1151-1155, 2005

15. Izci Y, Secer HI, Gönül E, Onguru O: Simultaneously occurring vestibular Schwannoma and meningioma in the cerebellopontine angle: Case report and literature review. Clin Neuropathol 26: 219-223, 2007

16. Kocabiyik N, Yalcin B, Kilic C, Ozan H, Kirici Y: Morphological study on rectus muscles of eye. Gulhane Med J 46(3):209-212, 2004 (in Turkish)

17. Oya S, Sade B, Lee JH: Sphenoorbital meningioma: Surgical technique and outcome. J Neurosurg 114: 1241-1249, 2001

18. Ringel F, Cedzich C, Schramm J: Microsurgical technique and results of a series of 63 spheno-orbital meningiomas. Neurosurgery 60(4 Suppl 2): 214-222, 2007

19. Saeed $P$, van Furth WR, Tanck $M$, Freling $N$, van der Sprenkel JW, Stalpers LJ, van Overbeeke JJ, Mourits MP: Surgical treatment of sphenoorbital meningiomas. Br J Ophthalmol 95: 996-1000, 2011

20. Saeed $P$, van Furth WR, Tanck M, Kooremans F, Freling N, Streekstra GI, Regensburg NI, van der Sprenkel JW, Peerdeman SM, van Overbeeke JJ, Mourits MP: Natural history of sphenoorbital meningiomas. Acta Neurochir (Wien) 153:395-402, 2011

21. Sandalcioglu IE, Gasser T, Mohr C, Stolke D, Wiedemayer H: Spheno-orbital meningiomas: Interdisciplinary surgical approach, respectability and long term results. J Craniomaxillofac Surg 33: 260-266, 2005

22. Scarone $P$, Leclerque $D$, Heran F, Robert G: Long-term results with exophthalmos in a surgical series of 30 sphenoorbital meningiomas. J Neurosurg 111: 1069-1077, 2009

23. Secer HI, Gonul E, Izci Y: Surgical management and outcome of large orbitocranial osteomas. J Neurosurg 109: 472-477, 2008

24. Shrivastava RK, Sen C, Costantino PD, Della Rocca R: Sphenoorbital meningiomas: Surgical limitations and lessons learned in their long-term management. J Neurosurg 103:491-497, 2005

25. Solmaz I, Pusat S, Kural C, Onguru O, Gonul E, Izci Y: Simultaneously occurring oligodendroglioma and meningioma: A rare synchronous primary brain tumors: Case report and literature review. Neurosurg Q 22: 133-136, 2012

26. Weber J, Gassel AM, Hoch A, Kilisek L, Spring A: Intraoperative management of cystic meningiomas. Neurosurg Rev 26(1): 62-66, 2003

27. Yannick N, Patrick F, Samuel M, Erwan F, Pierre-Jean P, Michel J, Stéphane V: Predictive factors for visual outcome after resection of spheno-orbital meningiomas: A long-term review. Acta Ophthalmol 90: e663-e665, 2012 